\title{
Inflation Expectations and Readiness to Spend: Cross-Sectional Evidence Online Appendix
}

\author{
Rüdiger Bachmann Tim O. Berg Eric R. Sims *
}

March 10, 2014

This online Appendix contains additional results to accompany "Inflation Expectations and Readiness to Spend: Cross-Sectional Evidence," to appear in the American Economic Journal: Economic Policy.

\section{Survey Questions Used}

Q 1 (A18)1 "About the big things people buy for their homes - such as furniture, a refrigerator, stove, television, and things like that. Generally speaking, do you think now is a good or a bad time for people to buy major household items?"

Q2 (A12b) "By about what percent do you expect future prices to go (up/down) on the average, during the next 12 months?"

Q 3 (A13b) "By about what percent per year do you expect prices to go (up/ down) on the average, during the next 5 to 10 years?"

Q 4 (A3) "Now looking ahead - do you think that a year from now you (and your family living there) will be better off financially, or worse off, or just about the sam as now? "

*Affiliations, respectively: RWTH Aachen University, CEPR, CESifo, and Ifo Institute (ruediger.bachmann@rwthaachen.de); Ifo Institute (berg@ifo.de); University of Notre Dame, NBER and Ifo Institute (esims1@nd.edu).

${ }^{1}$ The IDs beginning with the letter "A" are those used by the Michigan Survey. 
Q 5 (A14) "During the next year or two, do you expect that your (family) income will go up more than prices will go up, about the same, or less than prices will go up?"

Q6 (A11) "No one can say for sure, but what do you think will happen to interest rates for borrowing money during the next 12 months - will they go up, stay the same, or go down?"

Q 7 (A4) "Now turning to business conditions in the country as a whole-do you think that during the next 12 months we'll have good times financially, or bad times, or what? "

Q 8 (A8) "Looking ahead, which would you say is more likely - that in the country as a whole we'll have continuous good times during the next 5 years or so, or that we will have periods of widespread unemployment or depression, or what? "

Q 9 (A10) "How about people out of work during the coming 12 months - do you think that there will be more unemployment than now, about the same, or less? "

$\mathbf{Q} 10$ (A2) "We are interested in how people are getting along financially these days. Would you say that you (and your family living there) are better off or worse off financially than you were a year ago?"

Q 11 "To get a picture of people's financial situation we need to know the general range of income of all people we interview. Now, thinking about (your/ your family's) total income from all sources (including your job), how much did (you/ your family) receive in the previous year? "2

Q 12 (A9) "As to the economic policy of the government - I mean steps taken to fight inflation or unemployment - would you say the government is doing a good job, only fair, or a poor job?"

Q 13 (A23a) "What do you think the chances are that your (family) income will increase by more than the rate of inflation during the next five years or so?"

Q 14 (A23b) "During the next 5 years, what do you think the chances are that you (or your husband/ wife) will lose a job that you wanted to keep?"

\footnotetext{
${ }^{2}$ This question does not have an ID in the Michigan survey.
} 
Q 15 (A20c) "About how many cents per gallon do you think gasoline prices will (increase/ decrease) during the next twelve months compared to now?"

Q 16 (A19) "Speaking now of the automobile market-do you think the next 12 months or so will be a good time or a bad time to buy a vehicle, such as a car, pickup, van or sport utility vehicle?"

Q 17 (A20a) "About how many cents per gallon do you think gasoline prices will (increase/ decrease) during the next five years compared to now?"

Q 18 (A16) "Generally speaking, do you think that now is a good time or a bad time to buy a house?"

$\mathbf{Q} 19$ (A22b) "What do you think will happen to the prices of homes (like yours) in your community over the next 12 months? Will they increase at a rapid rate, increase at a moderate rate, remain about the same, decrease at a moderate rate, or decrease at a rapid rate?" 


\section{Basic Correlational Analysis}

In this appendix we explore some basic raw correlations between the one-year-ahead inflation expectations and the qualitative measures of readiness to spend (five-to-ten-years-ahead inflation expectations for the "readiness to spend on cars" question). ${ }^{3}$ This is a more model-free look at the data, which, as we will show, supports the econometric analysis in the main body of the paper. The results are reported in Table 8 . The correlation coefficient between expected inflation and the readiness to spend on durable goods is -0.047 when pooling observations across respondents and across time. This correlation is negative and small. In comparison, the bottom of the table shows the correlation between the reported readiness to spend and other idiosyncratic variables: expected aggregate business conditions, the current financial situation of the households, unemployment expectations and economic policy trust. These correlations are of the expected sign and are much larger in absolute value. In particular, the correlation between readiness to spend and expected aggregate business conditions (see Q7) is 0.222 . As with buying attitudes about durable goods, the correlations between expected inflation and readiness to spend on cars and houses are also negative (-0.049 and -0.093 , respectively), but still small in comparison to the correlations between readiness to spend and other idiosyncratic variables.

The remainder of Table 8 reports correlations between readiness to spend and expected inflation conditional on a variety of different demographic factors. These correlations are quite similar across groups, and with few exceptions range from -0.01 to -0.06 for readiness to spend on durables, similarly for readiness to spend on cars, and -0.08 to -0.10 for houses. Any differences between the magnitudes of the correlation coefficients appear to be quantitatively small and statistically indistinguishable.

Figure 8 plots the correlations between expected inflation and readiness to spend on durables, cars, and houses across time. The correlations are constructed by pooling the monthly observations within each year; the shaded gray regions are the 95 percent confidence intervals. The annual correlations typically range between 0 and -0.1 for all three spending categories and are, with few exceptions, significantly (in the statistical sense) negative. Importantly, the correlations for all three spending categories are quite stable, showing no obvious trend over time nor any clear relationship with the state of the business cycle. The notable exception is the recent zero lower bound episode, which, if anything, has seen a small decline of the already negative correlation coefficient, undermining somewhat the standard intuition of how inflation expectations ought to influence spending readiness during times of low interest rates.

\footnotetext{
${ }^{3}$ Notice that the survey in Q16 asks households whether the next twelve months or so will be a good or a bad time to buy a car, in contrast to the questions about household durables and houses, where the reference time is now. Given the wording of the question, we need to ensure that inflation expectations lie strictly in the future relative to the purchasing horizon. We thus account for the fact that the question asks not whether now is a good time to buy a car but instead refers to the next 12 months or so by pairing up the "readiness to spend on cars" question only with expected inflation over a five-to-ten-years horizon.
} 
Table 8: Correlation Between Reported Readiness to Spend and Expected Inflation

\begin{tabular}{|c|c|c|c|c|}
\hline & & \multicolumn{3}{|c|}{ Reported Readiness to Spend on } \\
\hline & & Durables & Cars & Houses \\
\hline \multicolumn{2}{|l|}{ All Respondents } & -0.047 & -0.049 & -0.093 \\
\hline \multirow[t]{2}{*}{ Gender } & Female & -0.044 & -0.042 & -0.094 \\
\hline & Male & -0.041 & -0.052 & -0.083 \\
\hline \multirow[t]{2}{*}{ Age } & Younger than 48 Years & -0.038 & -0.048 & -0.094 \\
\hline & Older than 48 Years & -0.059 & -0.052 & -0.092 \\
\hline \multirow[t]{5}{*}{ Race } & African American & -0.040 & -0.027 & -0.100 \\
\hline & Hispanic American & -0.041 & -0.041 & -0.090 \\
\hline & Native American & -0.038 & -0.031 & -0.074 \\
\hline & Asian American & -0.010 & -0.040 & -0.100 \\
\hline & Non-Hispanic Caucasian American & -0.048 & -0.050 & -0.090 \\
\hline \multirow[t]{2}{*}{ Education } & College Degree & -0.047 & -0.047 & -0.076 \\
\hline & No College Degree & -0.047 & -0.045 & -0.100 \\
\hline \multirow[t]{2}{*}{ Marital Status } & Married & -0.050 & -0.055 & -0.090 \\
\hline & Not Married & -0.042 & -0.040 & -0.092 \\
\hline \multirow[t]{4}{*}{ Family Size } & Single Person & -0.046 & -0.043 & -0.082 \\
\hline & Two Persons & -0.050 & -0.050 & -0.093 \\
\hline & Three Persons & -0.045 & -0.055 & -0.091 \\
\hline & Four and More Persons & -0.045 & -0.049 & -0.104 \\
\hline \multirow[t]{4}{*}{ Census Region } & West Region & -0.033 & -0.041 & -0.081 \\
\hline & Northeast Region & -0.038 & -0.051 & -0.086 \\
\hline & South Region & -0.061 & -0.049 & -0.107 \\
\hline & North Central Region & -0.045 & -0.054 & -0.091 \\
\hline \multirow{5}{*}{ Income Quintile } & Top 20 Percent Income Distribution & -0.026 & -0.045 & -0.073 \\
\hline & 60 to 80 Percent Income Distribution & -0.044 & -0.045 & -0.082 \\
\hline & 40 to 60 Percent Income Distribution & -0.045 & -0.045 & -0.081 \\
\hline & 20 to 40 Percent Income Distribution & -0.048 & -0.041 & -0.085 \\
\hline & Bottom 20 Percent Income Distribution & -0.048 & -0.041 & -0.083 \\
\hline \multirow[t]{2}{*}{ Homeownership } & Home Owner & -0.062 & -0.052 & -0.097 \\
\hline & Not Home Owner & -0.049 & -0.042 & -0.095 \\
\hline \multirow[t]{7}{*}{ Birth Cohort } & Born before 1920 & -0.033 & -0.008 & -0.064 \\
\hline & Born between 1920 and 1929 & -0.030 & -0.015 & -0.059 \\
\hline & Born between 1930 and 1939 & -0.063 & -0.053 & -0.105 \\
\hline & Born between 1940 and 1949 & -0.061 & -0.059 & -0.099 \\
\hline & Born between 1950 and 1959 & -0.051 & -0.067 & -0.109 \\
\hline & Born between 1960 and 1969 & -0.038 & -0.051 & -0.085 \\
\hline & Born after 1970 & -0.038 & -0.035 & -0.099 \\
\hline \multicolumn{5}{|c|}{ Pooled Correlation of Other Idiosyncratic Expectations With Reported Readiness to Spend } \\
\hline \multirow{3}{*}{\multicolumn{2}{|c|}{$\begin{array}{l}\text { Expected 1Y Aggregate Business Conditions (Idiosyncratic) } \\
\text { Expected 5Y Aggregate Business Conditions (Idiosyncratic) } \\
\text { Current Financial Situation }\end{array}$}} & 0.222 & 0.177 & 0.161 \\
\hline & & 0.168 & 0.174 & 0.161 \\
\hline & & 0.162 & 0.114 & 0.101 \\
\hline \multicolumn{2}{|c|}{ Expected Unemployment } & -0.139 & -0.135 & -0.126 \\
\hline \multicolumn{2}{|c|}{ Economic Policy Trust } & 0.169 & 0.154 & 0.126 \\
\hline
\end{tabular}

Notes: This table shows the correlation coefficients between inflation expectations and the reported readiness to spend on durables, cars and houses - pooled across all respondents as well as conditional on various demographics. We use one-year inflation expectations (Q??) for durables and houses, and five-to-ten-years inflation expectations (Q??) for cars. We have removed all month-household observations with inflation expectation observations that are larger than 20 percent in absolute value. This table also shows the correlation coefficients between the reported readiness to spend on durables, cars and houses - pooled across all respondents - and the idiosyncratically expected (1Y) aggregate business conditions, based on (Q7), the idiosyncratically expected (5Y) aggregate business conditions, based on (Q8), the current financial situation, based on (Q9), the expected unemployment situation, based on (Q10), and the trust of the household in current economic policy, based on (Q12). The sample period is 1984:01 to 2012:12. 
Figure 8: Time-Varying Correlation between Expected Inflation and Reported Readiness to Spend on Durables, Cars as well as Houses
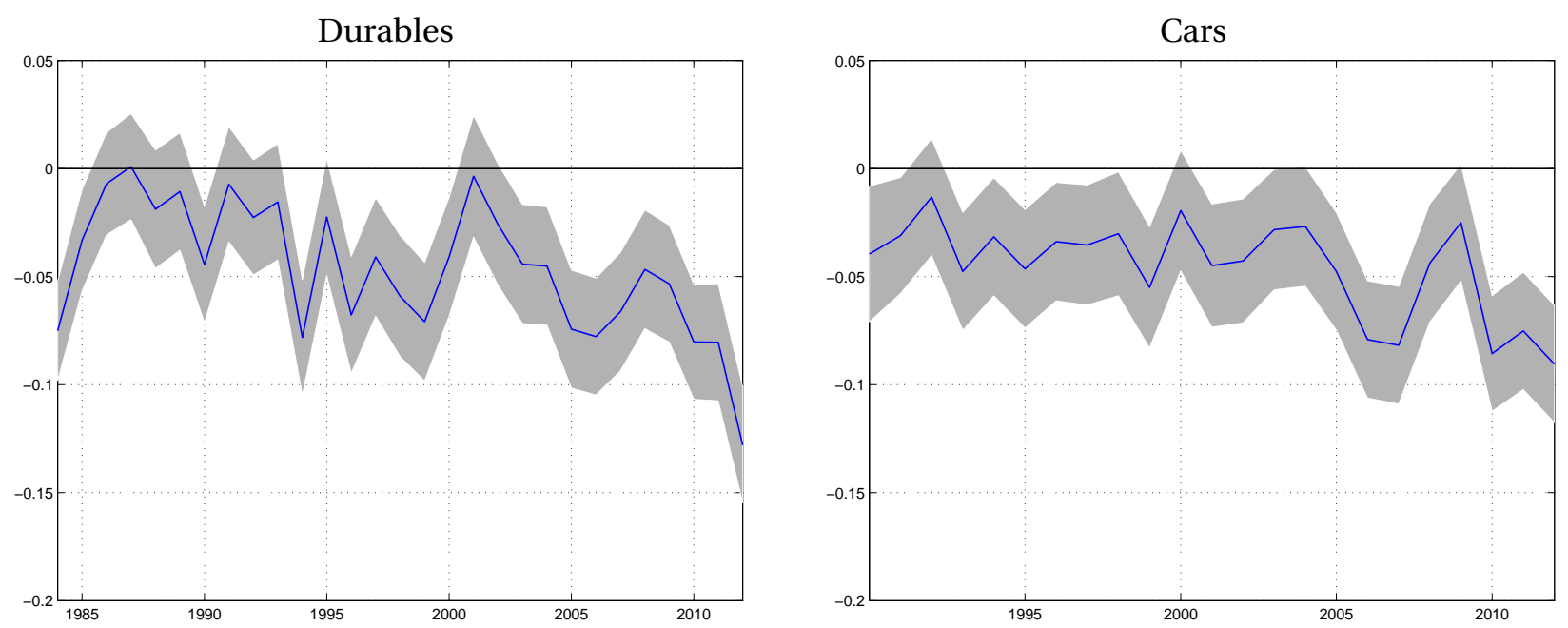

Houses

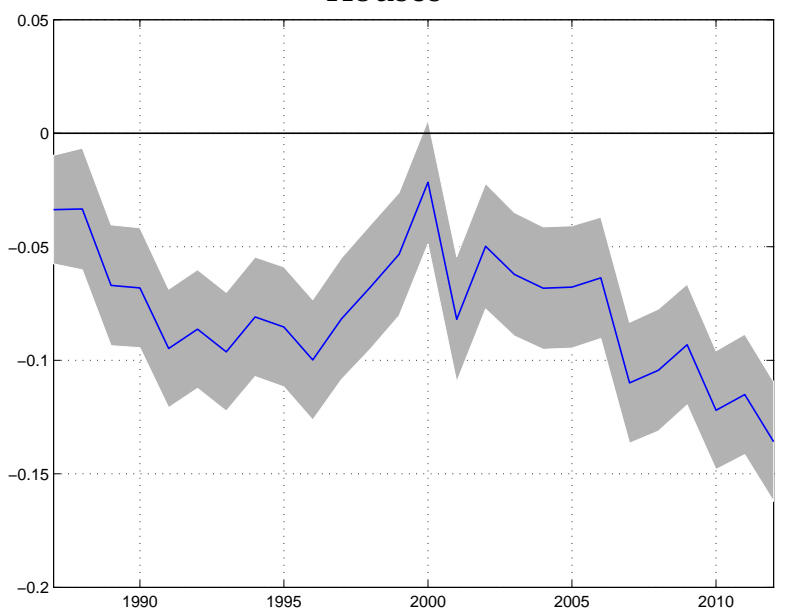

Notes: This figure shows the correlation coefficient between the reported readiness to spend on durables, cars, or houses (Q??, Q16, Q18) and inflation expectations (solid line) together with a 95 percent confidence interval (gray shaded area) year-by-year, where the monthly data were pooled within a year. We use one-year inflation expectations (Q??) for durables and houses, and five-to-ten-years inflation expectations (Q??) for cars. We have removed all month-household observations with inflation expectation observations that are larger than 20 percent in absolute value. The sample period is 1984:01 to 2012:12. 


\section{Reasons for (Not) Buying Durables, Cars, Houses}

In addition to asking about the readiness to spend on household durables, cars, and houses, the Michigan Survey of Consumers also asks households about their reasons for answering that it is a "good time" or a "bad time" to buy. ${ }^{4}$ Reasons for answering "good time" can be: "prices low", "prices going up", "interest rates low", "interest rates going up" and "good buys available" (which we rendered as "buyers' market" in Figure 9 below). Reasons for answering "bad time" can be: "prices high", "prices going down”, "interest rates right”, "interest rates going down” and "sellers' market". As explained in the main text, the survey, and apparently respondents, view increasing interest rates as a potential reason to spend now, if in the future loans can only be taken out at a higher cost to the households; the converse holds for declining interest rates as a potential reason not to spend now. In practice, neither forward-looking variable, prices nor interest rates, are particularly important for the readiness to spend, which is mainly explained by current prices and current interest rates and whether the households have the impression that they get generally good products that can be acquired with good services attached and low hassle. Figure 9 below documents this very clearly. Focusing on the future prices reason, Figure 10 shows that, if anything, during the zero lower bound episode this reason loses importance in almost all six cases (durables, cars, houses and good / bad times), the exception being houses and why it is a bad time to buy them, where households in recent times indeed expected further house price deflation and simply waited.

\footnotetext{
${ }^{4}$ Respectively, in survey questions (A18a) for durables, (A19a) for cars, and (A16a) for houses.
} 
Figure 9: Average Frequency of Reasons for (Not) Buying Durables, Cars, Houses
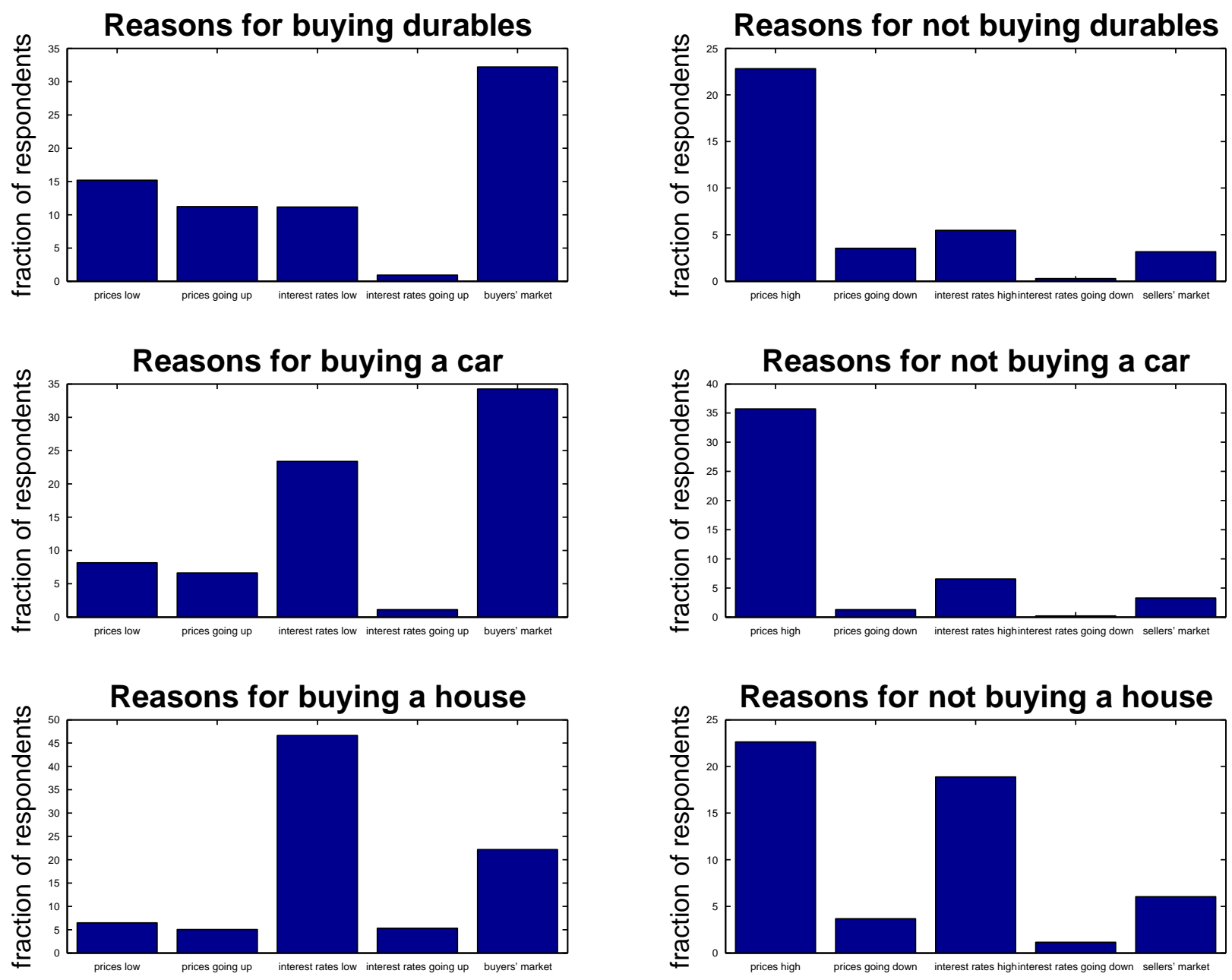

Notes: This figure plots the time series average of the fraction of respondents in each of the five categories of reasons for buying durables, cars and houses ("prices low", "prices going up", "interest rates low", "interest rates going up" and "good buys available", which we rendered as "buyers' market"), and the five categories for reasons for not buying them ("prices high", "prices going down", "interest rates right", "interest rates going down" and "sellers' market"). The sample period is 1984:01 to 2012:12. 
Figure 10: Time Series of the Frequency of Prices Going Up / Down
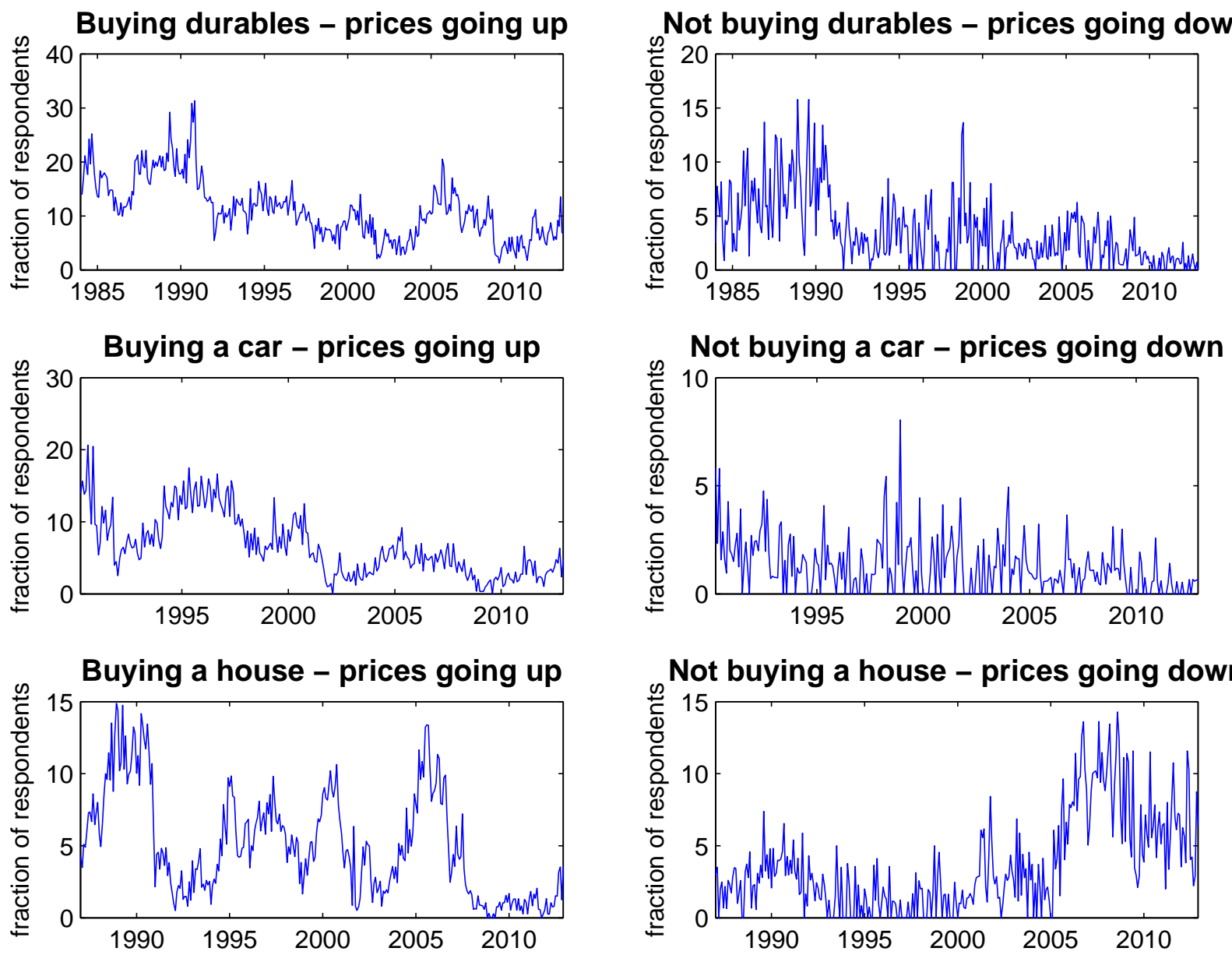

Notes: See notes to Figure 9. This figure plots the time series of the fraction of respondents for "prices going up" as a reason for buying durables, cars and houses, and the fraction of respondents for "prices going down" as a reason for not buying them. 


\section{Ordered Probit Results for the Readiness to Spend on Cars and Houses}

In this appendix we consider two extensions to our baseline estimation. In the first we use the responses to the "buying conditions for cars" question (Q16) instead of readiness to spend on durable household items; in the second we use buying attitudes about houses as the dependent variable (Q18). As with durable goods, both cars and houses are "big-ticket" purchases that ought to be sensitive to real interest rates and household wealth. Since the two main channels which proponents of "inflation-induced demand" point to are lowering real borrowing costs and devaluing existing debt, it is important to examine whether inflation expectations have effects on cars and houses.

Table 9 shows the results for cars, where we use the five-to-ten-years inflation expectations. ${ }^{5}$ In addition to all the baseline controls (plus the 'Home Owner' dummy), we also include as independent variables the expected change in gasoline prices over the next five years in cents per gallon (Q17) and an aggregate measure of the car loan rate, in percentage points. ${ }^{6}$ Qualitatively, the results are similar to those for durable household items. Increased five-to-ten-years inflation expectations reduce the probability that households report a positive attitude towards spending on cars. The effect is significantly negative at the zero lower bound, the marginal effect is 0.5 percentage points. Outside of the zero lower bound, the effect is essentially zero. For both additional controls, we obtain significant and plausible coefficient estimates and marginal effects. An increase in expected gasoline prices reduces the probability that households find buying conditions for cars favorable. Moreover, higher car loan rates are associated with a smaller probability that households have a positive attitude towards spending on cars.

As a second extension, we consider the question on buying conditions for houses, which asks whether now is a good or a bad time to buy a house (Q18). In addition to our standard set of controls, we add an aggregate measure of the 30-year mortgage rate (in percentage points) to the model to control for financing costs. ${ }^{7}$ Moreover, we include the S\&P Case-Shiller 10-City Home Price Index from FRED, expressed relative to the CPI. We take the natural logarithm of the series and then linearly detrend. This index is available only from 1987 onwards.

\footnotetext{
${ }^{5}$ Notice that the survey in Q16 asks households whether the next twelve months or so will be a good or a bad time to buy a car, in contrast to the questions about household durables and houses. Given the wording of the question, we need to ensure that inflation expectations lie strictly in the future relative to the purchasing horizon. We thus account for the fact that the question does not ask whether now is a good time to buy a car but instead refers to the next 12 months or so by pairing up the "readiness to spend on cars" question only with expected inflation over a five-to-ten-years horizon.

${ }^{6}$ We obtain the car loan rate series from the Federal Reserve Board of the Governors: "Terms of Credit at Commercial Banks and Finance Companies - New car loans at auto finance companies". It appears not to have been updated beyond 2010:12, which is why we use this time horizon for this specification.

${ }^{7}$ The mortgage rate series is from the Federal Reserve Board of the Governors. The series ID is MORTG.
} 
The results for the baseline specification with the "buying conditions for houses" question as the dependent variable are shown in the upper panel of Table 10. As one might expect, the mortgage rate and the level of current house prices both have significantly negative effects on buying attitudes about houses. Furthermore, the coefficient on the zero lower bound dummy is quite negative, which makes sense given that the period of the zero lower bound coincides with the collapse of the housing market. The coefficient on expected inflation is negative and statistically significant at the one percent level; the coefficient on the interaction term between expected inflation and the ZLB dummy is also negative. This is reflected in the estimated marginal effects: outside of the zero lower bound regime, expecting one percentage point more inflation over the next year is associated with a reduction in the probability of finding the present a good time to buy houses by 0.32 percentage points. At the zero lower bound this effect is even larger at 0.56 percentage points.

We consider two alternative specifications for the estimation with buying attitudes for houses. The results are shown in the second and third panels of Table 10. In the first, we measure inflation expectations over a five-to-ten-years horizon, which reduces the size of the available sample somewhat by restricting the start date to 1990:04. Houses are significantly more longlived than household durable goods, and hence expected inflation over a longer time horizon than one year may be more relevant for buying attitudes. The results are nonetheless fairly similar to the baseline - the coefficient on expected inflation is negative, though a little smaller in absolute value than in the benchmark. The marginal effect is negative both inside and outside of the zero lower bound regime, but is only significant during the zero lower bound regime.

The second alteration we consider is to include qualitative survey responses on subjective expectations about future house price changes. The data on one-year house price expectations (Q19) are not available for the period prior to May 2007. ${ }^{8}$ We also include as control variables the subjective probabilities of job loss and real income gains. The results are in the bottom panel of Table 10. The estimated coefficient and marginal effects of expected inflation are quite similar to what obtains in the full sample results shown in the upper panel. Increases in expected inflation make households less likely to report having a positive attitude towards buying a house, and this effect is even stronger during the zero lower bound period. Interestingly, households do understand that expected house price increases make now a good time to buy houses. This suggests that indeed households may understand the relevant relative price effect, but not the effects of general inflation and real interest rates.

\footnotetext{
${ }^{8}$ The qualitative house price expectations are coded ' +1 ' for an expected increase in house prices, ' 0 ' for no price change, and ' -1 ' for an expected decrease in house prices. Furthermore, we use only the sample until 2010:12, because afterwards there was a break in the survey design, in that the house price expectation question was only asked from homeowners and not from all survey participants anymore. Finally, the Michigan survey also asks for an expected percentage change in house prices. Unfortunately, this quantitative series shows a large number of missing observations, and hence we decided not to use it.
} 
Table 9: Readiness to Spend on Cars and 5Y Inflation Expectations

\begin{tabular}{|c|c|c|c|}
\hline Dependent Variable: Buying Conditions for Cars & \multicolumn{3}{|c|}{ Sample: $1990: 04$ to $2010: 12$} \\
\hline Number of observations: 28756 & \multicolumn{3}{|c|}{ Pseudo $R^{2}: 0.0416$} \\
\hline \multirow[b]{2}{*}{ Independent Variables } & \multirow[b]{2}{*}{ Coefficients } & \multicolumn{2}{|c|}{ Marginal Effects } \\
\hline & & at $D_{Z L B}=0$ & at $D_{Z L B}=1$ \\
\hline Inflation Expectations (5Y) & $\begin{array}{l}-0.0033 \\
(0.0027)\end{array}$ & $\begin{array}{l}-0.0012 \\
(0.0009)\end{array}$ & $\begin{array}{r}-0.0050^{* *} \\
(0.0024)\end{array}$ \\
\hline ZLB Dummy Interacted with Expected Inflation (5Y) & $\begin{array}{l}-0.0106 \\
(0.0072)\end{array}$ & & \\
\hline Expected Change in Gasoline Prices (5Y) & $\begin{array}{r}-0.0005^{* * *} \\
(0.0001)\end{array}$ & $\begin{array}{r}-0.0002^{* * *} \\
(0.0000)\end{array}$ & $\begin{array}{r}-0.0002^{* * *} \\
(0.0000)\end{array}$ \\
\hline Car Loan Rate & $\begin{array}{r}-0.0236^{* * *} \\
(0.0059)\end{array}$ & $\begin{array}{r}-0.0083^{* * *} \\
(0.0021)\end{array}$ & $\begin{array}{r}-0.0084^{* * *} \\
(0.0021)\end{array}$ \\
\hline
\end{tabular}

Notes: This table shows ordered probit results where the dependent variable is "Buying conditions for cars", based on (Q16), which is coded ' +1 ' for good, ' 0 ' for neither good nor bad, and ' 1 ' for bad. We add the car loan rate from the Federal Reserve Board of the Governors, the expected gasoline price change over the next five years in cents per gallon and based on (Q17), and the 'Home Owner' dummy as additional controls to the ones included in the baseline specification from the main text. Like the baseline specification this regression has been run on the subsample of the first interviews only. The sample period is 1984:01 to 2010:12. 
Table 10: Readiness to Spend on Houses and Inflation Expectations

\begin{tabular}{|c|c|c|c|c|}
\hline \multirow[b]{2}{*}{ Specification } & \multirow[b]{2}{*}{ Independent Variables } & \multirow[b]{2}{*}{ Coefficients } & \multicolumn{2}{|c|}{ Marginal Effects } \\
\hline & & & at $D_{Z L B}=0$ & at $D_{Z L B}=1$ \\
\hline \multirow{9}{*}{$\begin{array}{l}\text { Benchmark } \\
(N=60486, \\
\text { Sample: } 1987: 01 \text { to } 201\end{array}$} & Exp. Inflation (1Y) & $-0.0110^{* * *}$ & $-0.0032^{* * *}$ & $-0.0056^{* * *}$ \\
\hline & & $(0.0016)$ & $(0.0005)$ & $(0.0009)$ \\
\hline & ZLB Dummy $\times$ Exp. Inflation (1Y) & $-0.0080^{* *}$ & & \\
\hline & ZLB Dummy & $-0.6783^{* * *}$ & $-0.1948^{* * *}$ & \\
\hline & & $(0.0554)$ & $(0.0160)$ & \\
\hline & Mortgage Rate & $-0.0350^{* * *}$ & $-0.0100^{* * *}$ & $-0.0102^{* * *}$ \\
\hline & & $(0.0128)$ & $(0.0037)$ & $(0.0037)$ \\
\hline & S\&P Case-Shiller Index & $-0.0052^{* * *}$ & $-0.0015^{* * *}$ & $-0.0015^{* * *}$ \\
\hline & & $(0.0007)$ & $(0.0002)$ & $(0.0002)$ \\
\hline \multirow{12}{*}{$\begin{array}{l}\text { 5Y Expected Inflation } \\
(N=48501, \\
\text { Sample: } 1990: 04 \text { to } 201\end{array}$} & Exp. Inflation (5Y) & -0.0003 & -0.0001 & $-0.0032^{* *}$ \\
\hline & & $(0.0022)$ & $(0.0006)$ & $(0.0013)$ \\
\hline & ZLB Dummy $\times$ Exp. Inflation (5Y) & $-0.0107^{* *}$ & & \\
\hline & & $(0.0048)$ & & \\
\hline & ZLB Dummy & $-0.7938^{* * *}$ & $-0.2238^{* * *}$ & \\
\hline & & $(0.0651)$ & $(0.0182)$ & \\
\hline & Mortgage Rate & $-0.0687^{* * *}$ & $-0.0194^{* * *}$ & $-0.0202^{* * *}$ \\
\hline & & $(0.0153)$ & $(0.0043)$ & $(0.0045)$ \\
\hline & S\&P Case-Shiller Index & $-0.0075^{* * *}$ & $-0.0021^{* * *}$ & $-0.0022^{* * *}$ \\
\hline & & $(0.0008)$ & $(0.0002)$ & $(0.0002)$ \\
\hline & Home Owner & $0.1427^{* * *}$ & $0.0402^{* * *}$ & $0.0419 * * *$ \\
\hline & & $(0.0173)$ & $(0.0049)$ & $(0.0051)$ \\
\hline \multirow{20}{*}{$\begin{array}{l}\text { w/ Subj. Probabilities } \\
(N=5560, \\
\text { Sample: } 2007: 05 \text { to } 201\end{array}$} & Exp. Inflation(1Y) & $-0.0148^{* *}$ & $-0.0043^{* *}$ & $-0.0059 * * *$ \\
\hline & & $(0.0059)$ & $(0.0017)$ & $(0.0022)$ \\
\hline & ZLB Dummy $\times$ Exp. Inflation $(1 Y)$ & -0.0017 & & \\
\hline & & $(0.0077)$ & & \\
\hline & ZLB Dummy & -0.2657 & -0.0762 & \\
\hline & & $(0.2314)$ & $(0.0590)$ & \\
\hline & Subjective Prob. of Job Loss & -0.0010 & -0.0003 & -0.0003 \\
\hline & & $(0.0008)$ & $(0.0002)$ & $(0.0003)$ \\
\hline & Subjective Prob. of Real Income Gains & $0.0022 * * *$ & $0.0006^{* *}$ & $0.0008^{* *}$ \\
\hline & & $(0.0009)$ & $(0.0003)$ & $(0.0003)$ \\
\hline & Expected Change in House Prices (1Y) & $0.0719^{* *}$ & $0.0206^{* *}$ & $0.0255^{* *}$ \\
\hline & & $(0.0285)$ & $(0.0084)$ & $(0.0114)$ \\
\hline & Expected Change in Gas Price (1Y) & 0.0001 & 0.0000 & 0.0000 \\
\hline & & $(0.0005)$ & $(0.0001)$ & $(0.0002)$ \\
\hline & Mortgage Rate & -0.1895 & -0.0543 & $-0.0673^{*}$ \\
\hline & & $(0.1251)$ & $(0.0332)$ & $(0.0385)$ \\
\hline & S\&P Case-Shiller Index & $-0.0485^{* *}$ & $-0.0139 * *$ & $-0.0172^{* * *}$ \\
\hline & & $(0.0208)$ & $(0.0062)$ & $(0.0053)$ \\
\hline & Home Owner & $0.1803^{* * *}$ & $0.0517^{* * *}$ & $0.0640^{* * *}$ \\
\hline & & $(0.0544)$ & $(0.0163)$ & $(0.0235)$ \\
\hline
\end{tabular}

Notes: This table shows ordered probit results for three different specifications, each using as the dependent variable "Buying conditions for houses", based on Q18, which is coded ' +1 ' for good, ' 0 ' for neither good nor bad, and '-1' for bad. All of the standard controls from the benchmark specification are included. The upper panel shows results adding the mortgage rate from the Federal Reserve Board of Governors and the S\&P Case-Shiller 10 City Home Price Index, available from FRED, as additional controls. The middle panel is similar to the first but instead using inflation expectations over a five-to-ten year horizon. The final panel augments the specification in the first panel to include subjective one-year-ahead house price expectation series, Q19, but also Q13, Q14, and Q15. The number $N$ in parentheses refers to the number of observations used to estimate each specification; there the time horizon of the various samples is also specified. Like the baseline specification all these regressions have been run on the subsample of first interviews only. 


\section{A Control Function Approach}

A potential concern with our baseline specification is that survey-recorded inflation expectations may be observed or even reported with measurement error, which would work to bias the estimated coefficients towards zero. For example, survey respondents might put less effort into coming up with their best estimate for the inflation outlook when answering the survey as opposed to making actual purchasing decisions. On average their recorded survey responses may be right, but noisier than their true expectations.

We address this potential criticism by following the recommendation of Rivers and Vuong (1988), Wooldridge (2002), and Imbens and Wooldridge (2007) and employ a so-called control function (CF) approach to estimating the baseline specification. The CF approach is a twostage instrumental variable estimation method that can also be applied to nonlinear models. For this exercise, we make use of the panel dimension of the Michigan Survey of Consumers and focus on those households that were interviewed twice, using their first-interview inflation expectations as an instrumental variable. Given that inflation, and hence also expected inflation, is fairly persistent, lagged individual inflation expectations are an obvious instrument for current expected inflation.

In the first stage, we regress household inflation expectations from the second interview on all exogenous control variables from the baseline estimation plus the household inflation expectations from the first interview. The results for the first stage are shown in the upper panel of Table 11. Individual lagged inflation expectations enter the first stage with a coefficient of 0.22 that is highly statistically significant (the $t$ statistic is greater than 50), suggesting that first-interview inflation expectations constitute a reasonably strong instrument for secondinterview expected inflation.

In the second stage, we estimate our baseline ordered probit which includes expected inflation on the right hand side, and the residual from the first stage regression as an additional control variable. Including the residual from the first stage directly controls for any potential endogeneity in expected inflation; it also controls for potential endogeneity of functions of expected inflation, such as the interaction term between expected inflation and the zero lower bound dummy (see Imbens and Wooldridge, 2007). The second stage estimates are in the bottom panel of Table 11. The important result here is: the point estimates on the coefficients and marginal effects of interest - expected inflation and expected inflation interacted with the zero lower bound dummy - are again negative, now significantly so both inside and outside the zero lower bound regime, and, if anything, somewhat larger in absolute value than our baseline estimates. This is consistent with a small attenuation effect in the standard ordered probit due to the presence of measurement error. 
Table 11: Control Function Approach: Readiness to Spend on Durables and 1Y Inflation Expectations

\begin{tabular}{|c|c|c|c|}
\hline \multicolumn{4}{|l|}{ First Stage } \\
\hline $\begin{array}{l}\text { Dependent Variable: Individual Inflation Expectations (1Y) } \\
\text { Number of observations: } 53282\end{array}$ & \multicolumn{3}{|c|}{$\begin{array}{l}\text { Sample: } 1984: 01 \text { to } 2012: 12 \\
R^{2}: 0.1393 \\
\text { S.E. Residual: } 3.4083\end{array}$} \\
\hline Independent Variables & \multicolumn{2}{|l|}{ Coefficients } & \\
\hline Individual Lagged Inflation Expectations (1Y) & \multicolumn{2}{|l|}{$\begin{array}{r}0.2180^{* * *} \\
(0.0038)\end{array}$} & \\
\hline \multicolumn{4}{|l|}{ Second Stage } \\
\hline $\begin{array}{l}\text { Dependent Variable: Buying Conditions for Durables } \\
\text { Number of observations: } 51607\end{array}$ & \multicolumn{3}{|c|}{$\begin{array}{l}\text { Sample: } 1984: 01 \text { to } 2012: 12 \\
\text { Pseudo } R^{2}: 0.0751\end{array}$} \\
\hline \multirow[b]{2}{*}{ Independent Variables } & \multirow[b]{2}{*}{ Coefficients } & \multicolumn{2}{|c|}{ Marginal Effects } \\
\hline & & at $D_{Z L B}=0$ & at $D_{Z L B}=1$ \\
\hline Inflation Expectations (1Y) & $\begin{array}{r}-0.0174^{* *} \\
(0.0073)\end{array}$ & $\begin{array}{r}-0.0048^{* *} \\
(0.0020)\end{array}$ & $\begin{array}{r}-0.0129 * * * \\
(0.0029)\end{array}$ \\
\hline ZLB Dummy Interacted with Expected Inflation (1Y) & $\begin{array}{r}-0.0175^{* * *} \\
(0.0041)\end{array}$ & & \\
\hline First Stage Residual & $\begin{array}{r}0.0197^{* * *} \\
(0.0074)\end{array}$ & $\begin{array}{r}0.0054^{* * *} \\
(0.0020)\end{array}$ & $\begin{array}{r}0.0073^{* * *} \\
(0.0027)\end{array}$ \\
\hline
\end{tabular}

Notes: This table shows results from the control function approach to estimating the benchmark specification. The upper part of the table shows the first-stage regression results of individual inflation expectations (1Y) from the second-time interviews on the individual inflation expectations (1Y) from the first-time interviews. The same control variables as in the baseline estimation are included in the regression but their coefficients and standard errors are omitted for the sake of brevity. Following Wooldridge (2002) the estimated coefficient (marginal effect) in the second stage is computed from the standard ordered probit coefficient (marginal effect) divided by $\left[1+\left(\right.\right.$ coefficient on first-stage residual) ${ }^{2} \times$ (S.E. residual from first stage $\left.)^{2}\right]^{1 / 2}$. 